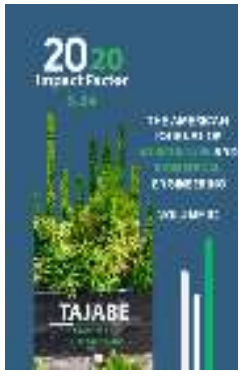

Journal Website: http://usajournalshub.c om/index,php/tajabe

Copyright: Original content from this work may be used under the terms of the creative commons attributes 4.0 licence.

\section{Efficiency Of Hormonal Insecticides In Fight Against Of Mulberry Pyralis}

\author{
Zarifa Gulomjanovna Nosirova \\ Xonoyim Abdukakhorovna Ergasheva \\ Assistant, Tashkent State Agrarian University, Uzbekistan
}

Doctor Of Science In Agricultural Sciences, Tashkent State Agrarian University, Uzbekistan

\title{
ABSTRACT
}

In the present paper the analysis of results of experiences carrying out on testing 5 hormonal affecting insecticides in fight against of mulberry pylalides from biologic active substances, namely Match - 1.0 litter/hectares, Nomolt - 0.3 litter/hectares, Binsegard - 0.5 kilogram/hectares, Al'familin - 0.5 litter/hectares and Rimon star 0.15 litter/hectares has been presented. In these experiences the values of the reached biologic efficiency in period of 15-16 days ones using were $81-100 \%$. Therefore the preparations mentioned above for including to the list of allowed pesticides in agriculture of Uzbekistan for practical using them by farmers producing silkworm cocoons have been recommended.

\section{KEYWORDS}

Biologic active substances, biologic efficiency, mulberry pyralid

\section{INTRODUCTION}

In managing the amount of mulberry moth (Diaphania pyloalis W.), which is an extreme pest of silkworm food stocks, it is an important task to test absolutely environmentally friendly means, given the current environmental situation. The role of hormonal insecticides in this regard is invaluable. This is due to the fact that they have a narrow exposure property and are absolutely safe for warm-blooded animals, humans and beneficial entomofauna. 
Hormonal insecticides affect the growth of harmful insects by shedding their skin, disrupting this process (metamorphosis) and aimed at (disrupting) [1-3]. This process occurs by producing secretions or hormones directly into the bloodstream through the endocrine glands of insects. They move throughout the body with the blood, controlling the metabolic process in the body and the development of the insect. Protorakol glands in the anterior chest of insects produce larval hormone or eczema in the blood.

This hormone ensures that peeling or ligation occurs in insects and stops the diapause [4]. and is produced in large numbers before the larva becomes a fungus or the fungus matures.

On the other hand, foreign bodies in the insect's body occasionally produce a hormone in the blood called a juvenile - a substance called neotein - that prevents the larva from becoming a mature species. As a result, the ratio of eczema to the juvenile hormone in the blood changes and peeling occurs. After the skin is removed, the juvenile hormone in the blood increases and the eczema decreases, while the opposite occurs before the next skin removal [3]. This is also the purpose of using hormonal drugs or juveniles.

One of the first drugs created for this purpose was Dimilin, a pure substance called diflubenzuron, which has been tested against many pests and has shown very high efficacy for some. For example, in Uzbekistan, the use of $30 \mathrm{~g} /$ ha against harmful locusts has given good results [3]. As a result of the use of this drug prolongs the age of the larvae of the pest. As a result, the body cracks and dies without being able to shed its skin.

In this study, the use of insecticides aimed at disrupting the development process through metamorphosis to control the amount of mulberry moth's main damage, ie in the worm phase, i.e. to artificially affect hormonal changes in the pest's body, was tested and recommended for production and practice. issues were considered.

\section{EXPERIENCES OBJECT AND METHODS}

The experiments were conducted in 2016-2017 on mulberry trees on a number of silkworm farms in Altinkul district of Andijan region.

To do this, we selected Match, Nomolt, Binsegard, Alfamilin, and Rimon Star hormonal insecticides and tested them against the first mulberry moth. We will give a brief description of the main properties of these drugs.

1. Nomolt, $15 \%$ s.k. The pure substance is teflubenzuron. Manufactured by the German concern BASF. It is an insecticide that affects the hormone management system of insects and has been tested against many harmful insects. In Uzbekistan, it is recommended to use this drug against locusts at a rate of $50 \mathrm{~g} / \mathrm{ha}$ [5]. We tested it at a rate of $0.2-0.31 /$ ha in the fight against mulberry moth.

2. Match, $5 \%$ em.k. A hormonal insecticide containing $5 \%$ of the active ingredient ? lufenuron. It is manufactured by the Swiss company Singenta Crope Proctage AG. Recommended insecticide against various pests. It has been recommended against apple caterpillar (1.0 I / ha), Colorado potato beetle ( $0.4 \mathrm{I} / \mathrm{ha}$ ) and others [5]. We tested it at a rate of 1.0-1.5 I/ ha in order to protect mulberry trees from mulberry moth.

3. Binsegard, $25 \%$ n.kuk. It contains $25 \%$ of the hormonal drug en phenoxycarb-containing insecticide, which was proposed by the Uzbek-German LLC "Evrotim". It is currently recommended to protect apples from leaf blight (0.5-0.6 I / ha) and tomatoes from cotton nightshade (0.4-0.5 I/ ha) [5]. We tested it at a rate of 0.4-0.5 I/ ha in the fight against mulberry moth.

4. Rimon Star, $6.5 \%$ em.k. Adama Agrikalcher B.V. of the Netherlands contains novaluron and bifentrin (talstar) insecticides. The 
drug is recommended for use against cotton bollworms and spiders - $0.15 \mathrm{I} / \mathrm{ha}$, against locusts in pastures (0.125-0.15 I / ha). We tested it in the fight against the mulberry moth by consuming it at a rate of $0.125-0.15$ I / ha.

5. Alfamilin, $17.6 \%$ sus.k. Contains a mixture of diflubenzuron (dimilin) and alphacipermethrin (fastak), designed to kill several pests at once. It is manufactured by the Belgian company Arista Life-Science Benelux Sprl. Currently, Alfamilin is recommended to protect orchard trees from apple worms (0.2-0.25 I/ ha). In our study, it was tested at a flow rate of 0.2$0.25 \mathrm{l} / \mathrm{ha}$ to safely protect the smoke from the propeller.

\section{EXPERIENCES RESULTS AND DISCUSSION}

In experiments, the drugs were sprayed on mulberries by motor spraying 2 times in June at 1-week intervals. Our experiments were carried out in 2 phases, in which we tested Match and Nomolt in Phase 1, while in Phase 2 we used the stars Binsegard, Alfamilin and Rimon. In doing so, we called the processes at each stage "early periods" and "late periods" respectively. Phase 1 experiments were conducted in 3 variants, Phase 2 in 4 variants, and 5 variants in each variant.

The distance between the mulberry bushes of the selected variants in the experiments was 700-800 $\mathrm{m}$, in which trees with almost the same degree of pest infestation were selected. At the same time, the amount of pest eggs and worms was recorded 5, 10, 15 days before and after treatment with the drug. Based on the results obtained, the values of biological efficiency obtained were calculated using the Abbott formula. The results obtained are presented in Tables 1 and 2.

As can be seen from Table 1, both Match and Nomolt showed high efficacy against the mulberry moth. In addition, "early spraying" is more effective. In our opinion, this may be due to the following factors:

1. One of the characteristics of hormonal insecticides is that they also have signs of ovicidality. That is, if a pest's egg is placed on a leaf that has been sprayed with the drug, the egg will be poisoned and the worm will not hatch.

2. The earlier (young) a worm is poisoned, the faster it dies during metamorphosis.

3. Butterflies that come into "contact" with air contaminated with a hormonal insecticide may become infertile or die prematurely.

All this indicates that such insecticides should be used when laying butterflies lay eggs.

From the data in Table 2, it can be seen that the active effect of some hormonal insecticides is higher and has been highly effective even in large young worms. All 3 insecticides tested also showed high efficacy against mulberry moth. The achieved biological efficiency gradually increased, reaching a peak (94-96\%) by day 15 , and a $95-100 \%$ result, especially for older young worms.

\section{CONCLUSIONS}

Thus, based on the analysis of the results of experiments to determine the effectiveness of the use of hormonal insecticides in the fight against mulberry moth in the mulberry groves of Altynkul district of Andijan region, we can list the following main results:

Among the biologically active substances against mulberry moth, 5 insecticides with hormonal properties were tested. These are: Match - 1.0 I / ha, Nomolt - 0.3 l / ha, Binsegard $0.5 \mathrm{~kg} / \mathrm{ha}$, Alfamilin - $0.5 \mathrm{l} / \mathrm{ha}$ and Rimon Star $0.15 \mathrm{I} / \mathrm{ha}$. At the same time, the values of biological efficiency achieved as a result of their application in 15-16 days were $81-100 \%$.

In this regard, it is recommended that the 5 hormonal insecticides listed above be included 
in the "List" of pesticides approved for future use in agriculture in Uzbekistan for practical use by farmers engaged in silkworm breeding in our country.

\section{REFERENCES}

1. Burov V.N., Sazonov A.P. Biological active substances in plants protection. - Moscow: Agropromizdat, 1987. $-196 \mathrm{p}$.

2. V. K. Rahmathulla, C. M. Kishor Kumar, B. S. Angadi, and V. Sivaprasad. Association of Climatic Factors on Population Dynamics of Leaf Roller, Diaphania pulverulentalis Hampson (Lepidoptera: Pyralidae) in Mulberry Plantations of Sericulture Seed
Farm // Hindawi Publishing Corporation Psyche. 2012, Article ID 186214, 6 pages.

3. Xo'jayev Sh.T. General and agricultural entomology and complex protection system basics. - Tashkent: Uzbekistan, 2019. $-362 \mathrm{p}$.

4. Bey-Biyenko G.Ya. General entomology. Moscow: Vysshaya shkola.-1980.- 490 p.

5. List of permitted in Uzbekistan pesticides for agrarian cultures (in Uzbek). Tashkent: State chemical commission, 2016. $-382 \mathrm{p}$.

Table 1

Biological efficiency of the hormonal insecticides in fight against mulberry pyralid (the field experiences, Andijan disrict, Altynkul district, 2016)

\begin{tabular}{|c|c|c|c|c|c|c|c|c|c|c|c|c|}
\hline \multirow{3}{*}{ № } & \multirow{3}{*}{ variants } & \multicolumn{5}{|c|}{$\begin{array}{l}\text { Quantity of mulberry pyralid eggs } \\
\text { and caterpillars on } 10 \text { rod, ps }\end{array}$} & \multicolumn{6}{|c|}{ Biological efficiency, \% /days: } \\
\hline & & \multicolumn{2}{|c|}{ Before processing } & \multicolumn{3}{|c|}{$\begin{array}{l}\text { Quantity of } \\
\text { caterpillars } \\
\text { after } \\
\text { processing }\end{array}$} & \multicolumn{2}{|c|}{5} & \multicolumn{2}{|c|}{10} & \multicolumn{2}{|c|}{16} \\
\hline & & eggs & caterpillars & 5 & 10 & 16 & $\hat{\mathbf{S}}$ & $\pm \mathrm{m}$ & $\hat{\mathbf{S}}$ & $\pm \mathrm{m}$ & $\hat{\mathbf{S}}$ & $\pm \mathrm{m}$ \\
\hline \multicolumn{13}{|c|}{ Earlier periods $\mathbf{- 1 4 . 0 6}$} \\
\hline 1. & $\begin{array}{l}\text { Match, 5\% em.c. } \\
\text { (lyufenuron) } \\
\text { ф. "Singenta", } \\
\text { Switzerland 1,0 } \\
\text { litter/hectare }\end{array}$ & 24 & 41 & 18 & 8 & 0 & 71,3 & 3,7 & 87,7 & 3,1 & 100 & - \\
\hline 2. & $\begin{array}{c}\text { Nomolt, } \mathbf{1 5} \% \\
\text { sus.c. } \\
\text { (teflubenzuron) } \\
\text { Basf firm, } \\
\text { Germany } \\
0,3 \text { litter/hectare }\end{array}$ & 43 & 56 & 21 & 13 & 4 & 75,5 & 4,5 & 85,4 & 2,7 & 93,6 & 0,8 \\
\hline 3. & $\begin{array}{l}\text { control (without } \\
\text { protection) }\end{array}$ & 64 & 32 & 49 & 51 & 36 & - & - & - & - & - & - \\
\hline \multicolumn{13}{|c|}{ Later periods -20.06} \\
\hline
\end{tabular}


The American Journal of Agriculture and Boimedical Engineering (ISSN - 2689-1018)

Published: November 10, 2020 | Pages: 1-6

\begin{tabular}{|c|c|c|c|c|c|c|c|c|c|c|c|c|}
\hline 1. & $\begin{array}{c}\text { Match, 5\% em.c. } \\
\text { (lyufenuron) } \\
\phi . \text { "Singenta", } \\
\text { Switzerland 1,0 } \\
\text { litter/hectare }\end{array}$ & 5 & 53 & 26 & 10 & 3 & 32,7 & 5,2 & 65,1 & 5,3 & 91,3 & 1,7 \\
\hline 2. & $\begin{array}{c}\text { Nomolt, 15\% } \\
\text { sus.c. } \\
\text { (teflubenzuron) } \\
\text { Basf firm, } \\
\text { Germany } \\
\text { o,3 litter/hectare }\end{array}$ \\
\hline 3. & 12 & 33 & 18 & 7 & 4 & 25,2 & 4,9 & 67,3 & 3,9 & 81,3 & 3,7 \\
\hline $\begin{array}{c}\text { control (without } \\
\text { protection) }\end{array}$ & 10 & 37 & 27 & 20 & 24 & - & - & - & - & - & - \\
\hline
\end{tabular}

Table 2

Biological efficiency of hormonal insecticides in fight against mulberry pyralid (the field experiences, Andijan disrict, Altynkul district, 2017)

\begin{tabular}{|c|c|c|c|c|c|c|c|c|c|c|c|c|}
\hline \multirow{3}{*}{ № } & \multirow{3}{*}{ variants } & \multicolumn{5}{|c|}{$\begin{array}{l}\text { Quantity of mulberry pyralid } \\
\text { eggs and caterpillars on } 10 \text { rod, } \\
\text { ps }\end{array}$} & \multicolumn{6}{|c|}{ Biological efficiency, \%/days: } \\
\hline & & \multicolumn{2}{|c|}{ Before processing } & \multicolumn{3}{|c|}{$\begin{array}{l}\text { Quantity of } \\
\text { caterpillars } \\
\text { after } \\
\text { processing }\end{array}$} & \multicolumn{2}{|c|}{4} & \multicolumn{2}{|c|}{9} & \multicolumn{2}{|c|}{15} \\
\hline & & eggs & caterpilalrs & 4 & 9 & 15 & $\hat{\mathbf{S}}$ & $\pm \mathrm{m}$ & $\hat{\mathbf{S}}$ & $\pm \mathrm{m}$ & $\hat{\mathbf{S}}$ & $\pm \mathrm{m}$ \\
\hline \multicolumn{13}{|c|}{ Earlier period - 17.06} \\
\hline 1. & $\begin{array}{c}\text { Binsegard, 25\% } \\
\text { n.powder } \\
\text { (fenoksikarb) } \\
\text { “Erotim" firm, } \\
\text { Uzbekistan -0,5 } \\
\text { kilogram/hectare }\end{array}$ & 3 & 38 & 20 & 4 & 1 & 61,9 & 2,7 & 94,2 & 0,9 & 96,7 & 1,4 \\
\hline 2. & $\begin{array}{c}\text { Alfamilin, } \mathbf{1 7 , 6 \%} \text { sus.c. } \\
\text { (alfa-sipermetrine + } \\
\text { diflubenzuron) } \\
\text { Belgium- } \\
0,5 \text { litter/hectare }\end{array}$ & 22 & 41 & 24 & 14 & 2 & 57,7 & 4,5 & 81,1 & 3,1 & 93,9 & 2,1 \\
\hline 3. & $\begin{array}{l}\text { Rimon Star, 6,5\% em.c. } \\
\text { (novaluron+bifentrin) } \\
\text { Nederland-0,15 } \\
\text { litter/hectare }\end{array}$ & 16 & 34 & 17 & 8 & 1 & 63,8 & 4,3 & 86,9 & 2,6 & 96,3 & 0,7 \\
\hline 4. & $\begin{array}{l}\text { control (without } \\
\text { protection) }\end{array}$ & 13 & 26 & 36 & 47 & 21 & - & - & - & - & - & - \\
\hline \multicolumn{13}{|c|}{ Later period - 25.06} \\
\hline 1. & Binsegard, $25 \%$ & 3 & 17 & 4 & 2 & 0 & 73,8 & 4,6 & 86,5 & 2,7 & 100 & - \\
\hline
\end{tabular}


The American Journal of Agriculture and Boimedical Engineering (ISSN - 2689-1018)

Published: November 10, 2020 | Pages: 1-6

Doi: https://doi.org/10.37547/tajabe/Volumeo2Issue11-01

2020: $5 \cdot 34$

OCLC - 1121105746

\begin{tabular}{|c|c|c|c|c|c|c|c|c|c|c|c|c|}
\hline $\begin{array}{c}\text { n.powder } \\
\text { (fenoksikarb) } \\
\text { "Erotim" firm, } \\
\text { Uzbekistan -0,5 } \\
\text { kilogram/hectare }\end{array}$ \\
\hline $\begin{array}{c}\text { Alfamilin, 17,6\% sus.c. } \\
\text { (alfa-sipermetrine+ } \\
\text { diflubenzuron) } \\
\text { Belgium- } \\
\text { o,5 litter/hectare }\end{array}$
\end{tabular}

